\title{
Differential effects of anticoagulants on tumor development of mouse cancer cell lines B16, K1735 and CT26 in lung
}

\author{
Tatjana M. H. Niers · Lois W. Brüggemann · Clara P. W. Klerk · \\ Femke J. M. Muller - Tessa Buckle - Pieter H. Reitsma - Dick J. Richel • \\ C. Arnold Spek · Olaf Van Tellingen · Cornelis J. F. Van Noorden
}

Received: 12 June 2008/ Accepted: 24 November 2008/Published online: 10 December 2008

(C) The Author(s) 2008. This article is published with open access at Springerlink.com

\begin{abstract}
Cancer progression is facilitated by blood coagulation. Anticoagulants, such as Hirudin and low molecular weight heparins (LMWHs), reduce metastasis mainly by inhibition of thrombin formation and L- and Pselectin-mediated cell-cell adhesion. It is unknown whether the effects are dependent on cancer cell type. The effects of anticoagulants on tumor development of K1735 and B16 melanoma cells and CT26 colon cancer cells were investigated in mouse lung. Tumor load was determined
\end{abstract}

T. M. H. Niers - C. P. W. Klerk - D. J. Richel

Department of Medical Oncology, Academic Medical Center, University of Amsterdam, Meibergdreef 9, 1105 AZ Amsterdam, The Netherlands

T. M. H. Niers - C. P. W. Klerk · F. J. M. Muller .

C. J. F. Van Noorden ( $\square)$

Department of Cell Biology and Histology, Academic Medical Center, University of Amsterdam, Meibergdreef 15,

1105 AZ Amsterdam, The Netherlands

e-mail: c.j.vannoorden@amc.uva.nl

L. W. Brüggemann · C. A. Spek

Center for Experimental and Molecular Medicine, Academic

Medical Center, University of Amsterdam, Meibergdreef 9,

1105 AZ Amsterdam, The Netherlands

\section{P. W. Klerk}

Department of Vascular Medicine, Academic Medical Center,

University of Amsterdam, Meibergdreef 9, 1105 AZ Amsterdam,

The Netherlands

T. Buckle $\cdot$ O. Van Tellingen

Department of Clinical Chemistry, Netherlands Cancer Institute, Plesmanlaan 121, 1006 CX Amsterdam, The Netherlands

P. H. Reitsma

Einthoven Laboratory for Experimental Vascular Medicine,

Leiden University Medical Center, 2333 ZA Leiden,

The Netherlands noninvasively each week up to day 21 in all experiments using bioluminescence imaging. Effects of anticoagulants on tumor development of the three cell lines were correlated with the fibrin/fibrinogen content in the tumors, expression of tissue factor (TF), protease activated receptor (PAR)-1 and -4 and CD24, a ligand of L- and P-selectins. Hirudin inhibited tumor development of B16 cells in lungs completely but did not affect tumor growth of K1735 and CT26 cells. Low molecular weight heparin did not have an effect on K1735 melanoma tumor growth either. TF and PAR-4 expression was similar in the three cell lines. PAR1 and CD24 were hardly expressed by K1735, whereas CT26 cells expressed low levels and B16 high levels of PAR-1 and CD24. Fibrin content of the tumors was not affected by LMWH. It is concluded that effects of anticoagulants are dependent on cancer cell type and are correlated with their CD24 and PAR-1 expression.

Keywords B16 melanoma - CT26 colon carcinoma . K1735 melanoma · Hirudin .

Low molecular weight heparin $\cdot$ Selectin $\cdot$ PAR

$\begin{array}{ll}\text { Abbreviations } \\ \text { LMWH } & \text { Low-molecular-weight heparin } \\ \text { TF } & \text { Tissue factor } \\ \text { PAR } & \text { Protease-activated receptor } \\ \text { TFPI } & \text { Tissue factor pathway inhibitor } \\ \text { FVL } & \text { Factor V Leiden } \\ \text { aXa } & \text { Anti-Xa } \\ \text { PBS } & \text { Phosphate-buffered saline } \\ \text { PE } & \text { Phycoerythrin } \\ \text { PEG } & \text { Polyethylene glycol } \\ \text { BLI } & \text { Bioluminescence } \\ \text { ROI } & \text { Region of interest }\end{array}$


FACS Flow-activated cell sorter

SEM Standard error of the mean

\section{Introduction}

A frequent haematological complication in cancer patients is disordered coagulation. The association between cancer and venous thromboembolic events is well recognized [1, 2]. Cancer cells can produce activators of the coagulation cascade and thus potential beneficial effects of anticoagulants are investigated for prevention or treatment of cancer [3,4]. Clinical trials evaluated the effects of low molecular weight heparins (LMWHs) on survival of cancer patients without thrombosis [5-9]. Overall, there was no difference in survival, but three studies $[5,7,8]$ defined a priori a subgroup consisting of patients with a relatively good prognosis at enrolment. Patients in this defined subgroup had a significant survival benefit when treated with LMWHs. These clinical reports are supported by experimental in vitro and in vivo studies showing that spontaneous and induced metastasis is significantly inhibited by anticoagulants [3, 4].

However, mechanisms of the effects of anticoagulants on cancer progression are still not exactly known. Animal studies showed that different components of the coagulation system, such as tissue factor (TF) [10], factor Xa [11], thrombin [12] and fibrinogen [13] can promote tumor progression, whereas the TF pathway inhibitor (TFPI) inhibits tumor growth in mice [14]. The congenital coagulation disorder FV Leiden (FVL) promotes melanoma tumor development in mouse lung, whereas FVIII-deficient (haemophilic) mice are protected against melanoma tumor growth in lungs indicating a role for the coagulation process [15]. However, a lack of effects of FVL has been observed as well in colon cancer tumor development in mouse liver [16] indicating that the coagulation system is not effective in all organs. Moreover, not all anticoagulants are effective inhibitors of cancer progression [17-19].

The anticancer properties of anticoagulants appear to be mediated by various mechanism $[3,4]$ but blocking P- and L-selectins has major effects [17-20]. In the present study, we focussed on inhibition of thrombin formation and platelet-cancer cell complex formation by anticoagulants. These processes are closely related. Cancer cells often express TF on their surface which can trigger thrombin formation and procoagulant activity of platelets. Thrombin is the most potent activator of platelets via protease activated receptors (PARs) [21, 22]. PAR signalling induces upregulation of adhesion molecules on endothelial cells and thus binding of platelets via P-selectin. Cancer cells can also upregulate P-selectin expression on platelets and endothelial cells, whereas cancer cells can express P- selectin ligands, such as CD24 and Sialyl Lewis x/a- on their plasma membrane [23]. Their interactions result in the formation of platelet-cancer cell complexes that favour survival of cancer cells in the circulation [20, 24-26] by protecting cancer cells against the immune system and mechanical stress. Anticoagulants, including LMWH and Hirudin, prevent binding of platelets to cancer cells [17, 20]. Furthermore, thrombin converts fibrinogen into fibrin. Fibrin depositions have been found in and around various types of tumors, providing scaffolding for angiogenesis and possibly protecting cancer cells against the host defence as well [27, 28; Klerk et al. submitted].

In the present study, we explored underlying mechanisms of the effects of anticoagulants on cancer by analysing the effects of Hirudin and LMWH on tumor development of three different cancer cell lines in mouse lungs. We also investigated the fibrin/fibrinogen content in tumors and expression of TF and adhesion molecules by the cancer cells.

\section{Materials and methods}

\section{Cancer cell lines}

Three mouse cancer cell lines expressing luciferase were used in experimental models of metastasis in mouse lungs, the B16 mouse melanoma cell line (American Type Culture Collection, Manassas, VA) [29], the K1735 mouse melanoma cell line (kindly provided by Dr. I.J. Fidler, MD Anderson Cancer Institute, Houston, TX), and the CT26 mouse colon carcinoma cell line (also kindly provided by Dr. I.J. Fidler) were used. Preparation of cell cultures, transfection with the luciferase gene and inoculation of the cells in the tail vein of mice have been described previously $[30,31]$.

\section{TF activity}

TF activity of the three cell lines was measured to test their ability to induce coagulation using a standard procoagulant activity assay (also known as the one-stage clotting assay or recalcification assay) [32]. Cancer cells were suspended in PBS at a concentration of $7.5 \times 10^{4}$ cells $/ \mathrm{ml}$ and $75 \mu \mathrm{l}$ of the cell suspensions was added to $75 \mu \mathrm{l}$ mouse plasma (Sigma, St. Louis, MO) and incubated at $37^{\circ} \mathrm{C}$ for $2 \mathrm{~min}$. Then, $100 \mu \mathrm{l}$ of a $25 \mathrm{mM}$ calcium chloride solution was added and the clotting time was measured using a KC-10 coagulometer (Amelung, Lemgo, Germany).

\section{Flow cytometry}

Flow cytometric analysis of the three cancer cell lines was performed to determine the presence of various surface 
proteins. Cancer cells were incubated in the absence of serum during $24 \mathrm{~h}$ before flow cytometric analysis. Cancer cells were centrifuged at $400 \mathrm{~g}$ for $5 \mathrm{~min}$. Cells were washed twice with flow-activated cell sorter (FACS)-buffer (PBS supplemented with $0.5 \%$ bovine serum albumin, $0.01 \%$ $\mathrm{NaN}_{3}$, and $0.35 \mathrm{mM}$ EDTA) and finally suspended in FACS buffer $\left(4 \times 10^{6}\right.$ cells $\left./ \mathrm{ml}\right)$. For each analysis, at least $1 \times 10^{5}$ cells were analyzed using a FACS Calibur flow cytometer (Becton Dickinson, Mountain View, CA). Fc receptors were blocked with purified anti-mouse CD16/32 antibodies (dilution, 1:50; Fcy 111/11 receptor; Pharmingen, BD Biosciences, Breda, The Netherlands). Staining was performed using rat anti-mouse CD24 antibody coupled with phycoerythrin (PE) (dilution, 1:50; Pharmingen, BD Biosciences), goat anti-mouse PAR-4 antibody (dilution, 1:50; M-20 Santa Cruz Biotechnology, Heidelberg, Germany) and rabbit anti-mouse PAR-1 (dilution, 1:50; thrombin R; H-111 Santa Cruz Biotechnology). As secondary antibody antirabbit coupled with Alexa fluor 488 (dilution, 1:150; Molecular Probes, Eugene, OR) was used to detect PAR-1 expression and anti-goat coupled with FITC (dilution, 1:200; Dako) was used to detect PAR-4 expression. To correct for nonspecific staining; all analyses were also conducted with cells stained with the appropriate isotype control antibodies. Cancer cells were identified by forward and sideangle light scatter gating. Data are presented as the difference between mean fluorescence intensities of specifically stained and nonspecifically stained cells.

\section{Animals}

For all experiments, eight weeks-old Balb-/c nude mice with a body weight of 20-27 g were used (Netherlands Cancer Institute, Amsterdam, The Netherlands). Animals were maintained under constant environmental conditions with free access to food and water. All animal experiments were performed in agreement with the Animal Ethics Committee of the Netherlands Cancer Institute.

\section{Lung colonization model}

Thirty mice received $3 \times 10^{5} \mathrm{~K} 1735$ cells, twenty mice received $3 \times 10^{5}$ B16 cells and twenty mice received $3 \times 10^{5}$ CT26 cells into the tail vein. Half of the mice in each group received $10 \mathrm{mg} / \mathrm{kg}$ polyethylene glycol (PEG)Hirudin (Abbott, Knoll, Ludwigshafen, Germany) subcutaneously before cancer cell inoculation. The other half of the mice received PBS subcutaneously before cancer cell inoculation. Mice were sacrificed at 21 days after cancer cell inoculation and lungs were harvested.

Furthermore, 15 mice received $3 \times 10^{5}$ K1735 cells into the tail vein. Ten mice received 600 anti-Xa (aXa) IU nadroparin (Sanofi-Synthelabo, Berlin, Germany) intraperitoneally per $\mathrm{kg}$ body weight prior to cancer cell inoculation. The other mice received PBS intraperitoneally and served as controls. Mice were sacrificed at 21 days after cancer cell inoculation and lungs were harvested.

\section{Bioluminescence imaging (BLI)}

For all experiments, cancer cell load in lungs was measured at day $1,7,15$ and 21 after administration of the cancer cells using noninvasive BLI as previously described [30, 31]. To generate BLI by luciferase, its substrate, luciferin (Xenogen, Alameda, CA) was given intraperitoneally to the mice $(150 \mathrm{mg} / \mathrm{kg}$ body weight). Luciferase converts luciferin into oxyluciferin and the resulting BLI was imaged with the use of a highly sensitive cooled chargecoupled device camera in a lighttight chamber (IVIS Imaging System 100 series; Xenogen). The acquired images were analyzed with the software program Living Image $^{\mathrm{R}} 2.11$ (Xenogen). The area of the lungs was selected as region of interest (ROI) for the quantification of BLI.

\section{Histochemistry}

Lungs were analyzed microscopically in order to determine whether LMWH altered fibrin/fibrinogen depositions in the tumors. Cryostat sections ( $6 \mu \mathrm{m}$ thick) were cut at a cabinet temperature of $-25^{\circ} \mathrm{C}$ using a motor-driven cryostat (Bright, Huntingdon, UK) and stored at $-25^{\circ} \mathrm{C}$ until used. Cryostat sections were air dried for $60 \mathrm{~min}$ at room temp. Sections were fixed in $4 \%(\mathrm{v} / \mathrm{v})$ formaldehyde in distilled water for $20 \mathrm{~min}$ and rinsed 3 times in PBS afterwards. Then, endogenous peroxidase was inhibited by incubating sections in $0.3 \%(\mathrm{v} / \mathrm{v}) \mathrm{H}_{2} \mathrm{O}_{2}$ and $0.1 \%(\mathrm{w} / \mathrm{v}) \mathrm{NaN}_{3}$ in distilled water for $20 \mathrm{~min}$ at room temp. After rinsing 3 times in PBS, sections were incubated in PBS supplemented with $10 \%$ (v/v) normal rabbit serum (Dako, Glostrup, Denmark) for $15 \mathrm{~min}$ at room temp as blocking step. This incubation step and all following incubation steps with antibodies were performed in a humidified chamber. A goat monoclonal antibody against mouse fibrinogen that cross reacts with fibrin (Accurate Chemical and Scientific Corp, Westbury, NY) was used as primary antibody. The antibody was diluted 1:500 in PBS in the presence of $1 \%$ bovine serum albumin. Sections were incubated for $60 \mathrm{~min}$ at room temp. After rinsing 3 times in PBS, the secondary antibody, rabbit anti-goat immunoglobulin coupled to horseradish peroxidase (Dako) diluted 1:100 in PBS in combination with $0.2 \%(\mathrm{w} / \mathrm{v})$ bovine serum albumin and $5 \%$ (v/v) normal mouse serum (Dako) was applied and sections were incubated for $60 \mathrm{~min}$ at room temp. Binding of secondary antibodies was visualized using a solution of $10 \mathrm{mM}$ diaminobenzidine (Fluka, Buchs, Switzerland), $10 \mathrm{mM} \mathrm{NaN}$ and $4 \%$ (v/v) $\mathrm{H}_{2} \mathrm{O}_{2}$ in $50 \mathrm{mM}$ Tris- $\mathrm{HCl}$ 
buffer, $\mathrm{pH}$ 7.6, for $10 \mathrm{~min}$ at room temp. Control incubations were performed in the absence of the primary antibody in the incubation medium. Subsequently, the sections were rinsed 3 times in distilled water and counterstained with haematoxylin (' $Z$ ' stain; Cellpath, Newton Powys, UK) for $5 \mathrm{~s}$. After $10 \mathrm{~min}$ of rinsing in tab water, sections were mounted in glycerin-gelatin.

\section{Statistical analysis}

BLI data were compared using the Mann-Whitney U-test (unpaired, non-normally distributed groups). Values were given as median. $P$ values $<0.05$ were considered to indicate significant differences.

\section{Results}

\section{Characteristics of B16, K1735 and CT26 cells}

Procoagulant TF activity of the three cancer cell lines was not significantly different (Fig. 1).

Fig. 2 shows that a distinct fraction of B16 cells was positive for PAR-1 and CD24, whereas a smaller fraction of CT26 cells was positive for PAR-1 and an even smaller fraction was moderately positive for CD24. K1735 cells were not positive for any of the adhesion molecules. PAR-4 was not expressed on any of the cell types.

\section{BLI}

The brightest BLI in the mice was found in the ROI, the lungs. BLI was measured weekly. Fig. 3 shows the

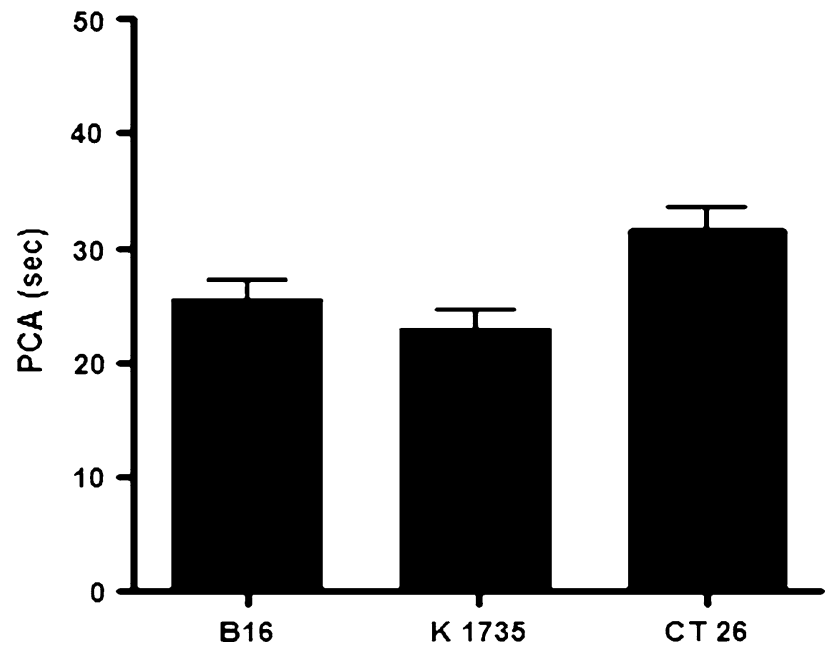

Fig. 1 Tissue factor (TF) activity in cultured cancer cells. TF activity was determined in $7.5 \times 10^{4}$ cells and expressed as procoagulant activity (PCA) in seconds (mean \pm SEM). PCA was inversely related to $\mathrm{TF}$ activity and was not significantly different in B16, K1735 or CT26 cells ( $P$-values were $0.39,0.14$ and 0.08 , respectively) exponential increase in time of BLI values in the ROI. Some mice showed BLI in the tail vein at the site of cancer cell inoculation (Fig. 4) and in the abdominal area, indicating cancer spread to abdominal organs.

\section{Effects of Hirudin}

Hirudin strongly inhibited B16 melanoma tumor development in lungs, whereas tumor development of K1735 cells and CT26 cells was not affected (Table 1).

\section{Effects of LMWH}

K1735 melanoma cells induced tumors in lungs of mice irrespective of treatment. A bolus of LMWH before cancer cell inoculation did not affect the growth rate of the tumors in the lungs. This is confirmed by the bioluminescence values of all mice at day 21 after cancer cell inoculation (Fig. 5).

\section{Fibrin/fibrinogen content}

Fibrin/fibrinogen content in K1735 melanoma tumors in lungs was similar in LMWH-treated mice and control mice.

\section{Discussion}

Double-blind placebo-controlled randomized studies have shown a significant life-prolonging effect in cancer patients treated with LMWH $[5-7,9]$. Therefore, it is important to optimize treatment of cancer patients with LMWH and/or possibly other anticoagulants and maximize these effects. Murine models of experimental metastasis have been used frequently to investigate the effect of anti-haemostatic agents on cancer metastasis. Although such artificial models do not encompass the entire metastatic process, they remain useful for 'proof-of-concept'-experiments, focusing on the haematogenous phase of tumor dissemination. Several studies have demonstrated significant efficacy of anticoagulants [3, 4].

In this study, we determined the effects of Hirudin on the development of K1735, B16 melanoma and CT26 colon cancer tumors in mouse lungs and the LMWH nadroparin on the development of K1735 melanoma tumors. Hirudin, a strong inhibitor of thrombin, was not able to inhibit tumor development of K1735 melanoma cells and CT26 colon cancer cells, whereas the inhibitory effect on tumor development of B16 cells was as potent as has been demonstrated before [12]. Moreover, LMWH did not have any inhibitory effect on tumor growth of K1735 melanoma cells either. The different effects of Hirudin cannot be explained by differences in thrombin or fibrin production 
Fig. 2 FACS analysis of PAR1, PAR-4 and CD24 expression. Fluorescence is shown on the $\mathrm{X}$ axis on a logarithmic scale and positive cells on the $\mathrm{Y}$-axis as percentage of the control peak. PAR-1 was found in significant fractions of B16 and CT26 cells but not K1735 cells, PAR-4 expression was not found in any of the three cell lines. CD24 was expressed on a large part of the B16 cells, a small fraction of CT26 cells and not on K1735 cells. Grey areas represent control cells; black areas represent positive cells
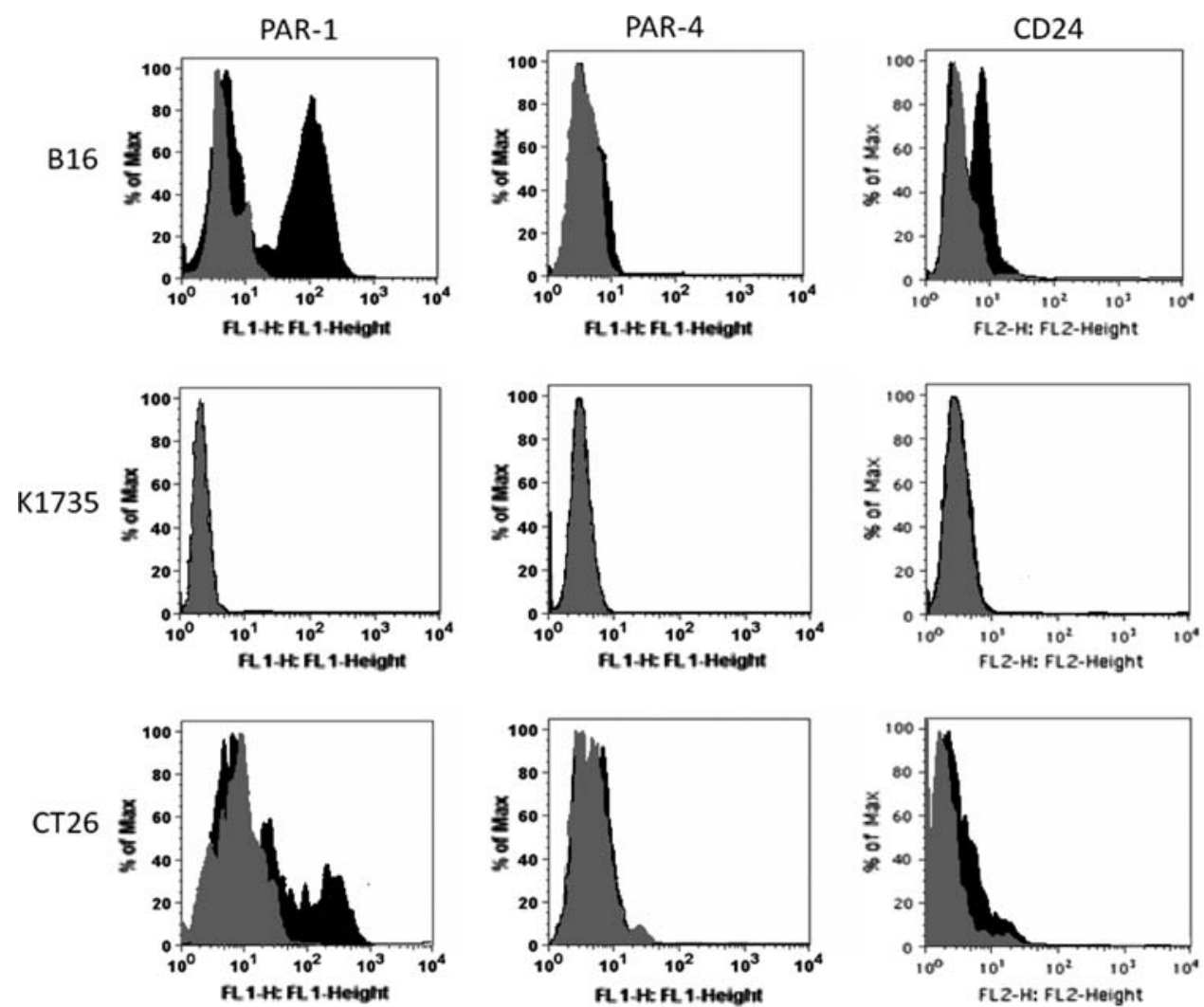

Fig. 3 Noninvasive

bioluminescence imaging of an individual mouse on days 1,7 , 15 and 21 after intravenous administration of B16 melanoma cells. The bioluminescence signal as a measure of cancer cell load in the region of interest (ROI) increased from below the detection limit (ND) on day 1 to $0.23 \times 10^{5}, 2.6 \times 10^{5}$ and $110 \times 10^{5}$ photons/s at days 7 , 15 and 21 , respectively
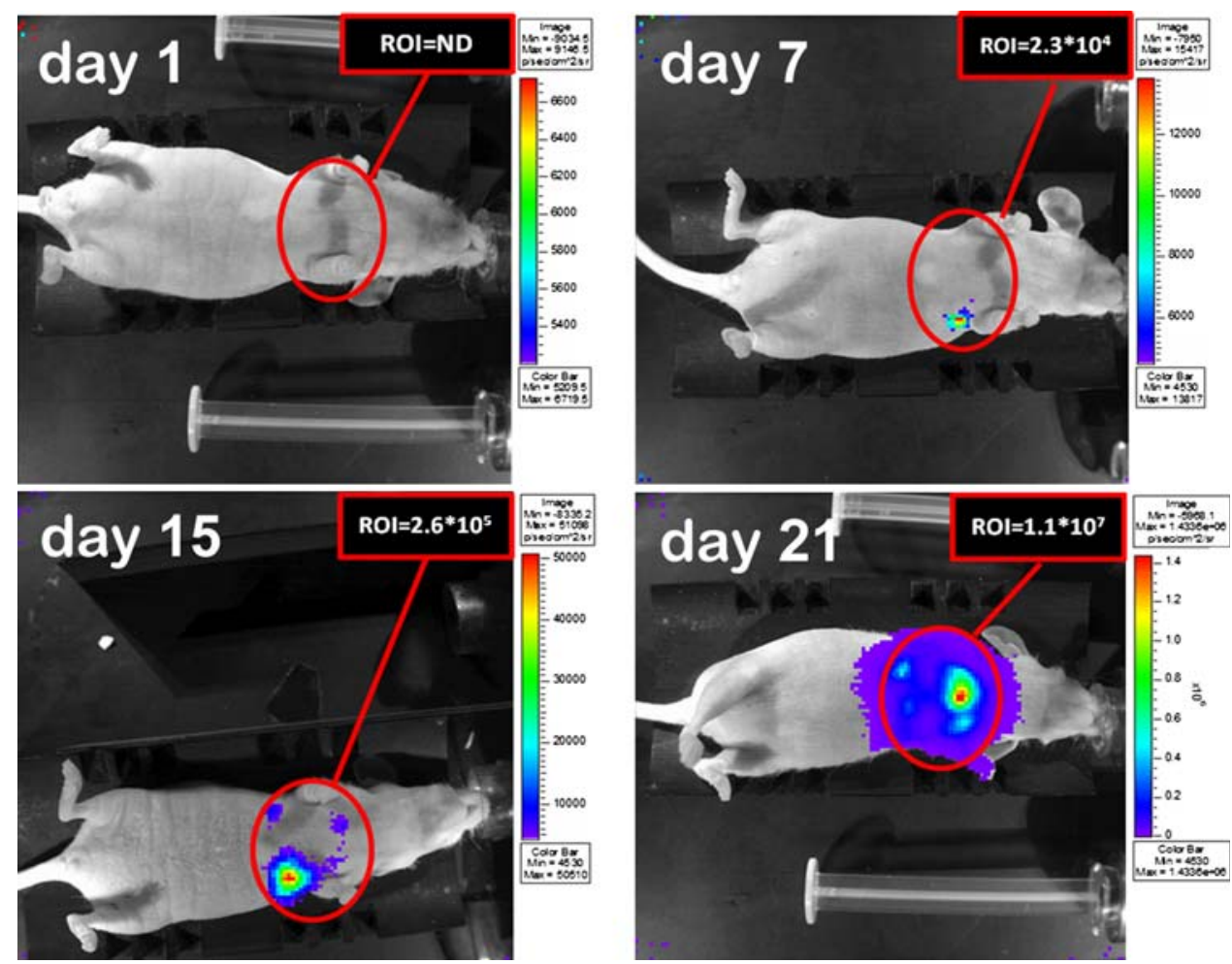

because the TF activity was comparable in the three cancer cell lines. These findings indicate that mechanisms are involved other than the coagulation cascade.
Thrombin binds PAR-1 and mediates increased invasiveness and metastatic potential of cancer cells [33-35] and enhanced cancer cell adhesion to platelets [36-38], 


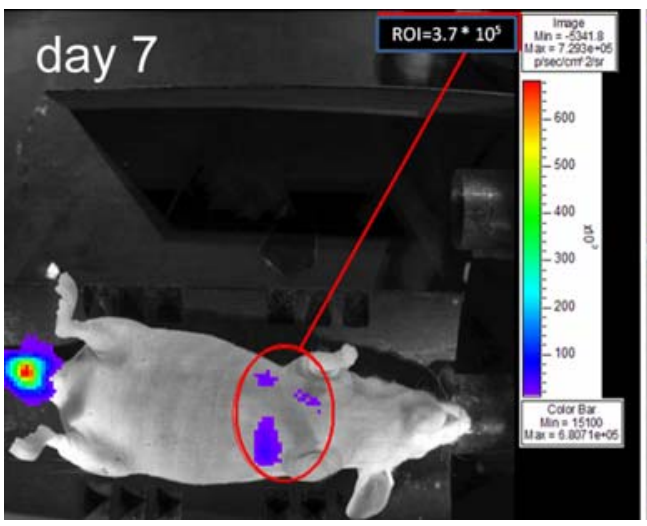

Fig. 4 Noninvasive bioluminescence imaging in an individual mouse on days 7 and 21 after intravenous administration of luciferaseexpressing B16 melanoma cells into the tail vein. The mouse shows bioluminescence in the tail indicating the presence of cells at the site

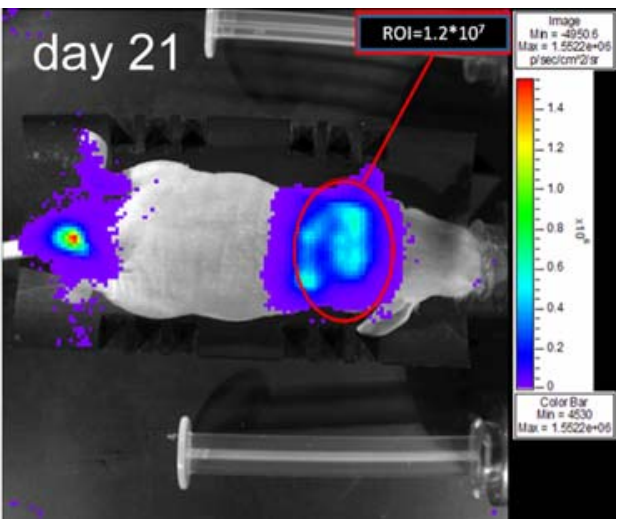

of cancer cell inoculation. The region of interest (ROI) for bioluminescence measurements is given in red, showing a cancer cell load of $3.7 \times 10^{5}$ and $120 \times 10^{5}$ photons/s, at days 7 and 21 , respectively

Table 1 Bioluminescence in mice at day 21 after B16, K1735 and CT26 cancer cell inoculation

\begin{tabular}{llll}
\hline Cell line & Hirudin & No Hirudin & $P$-value \\
\hline B16 & 0 & $200 \times 10^{5}$ & 0.04 \\
& & $\left(0.73 \times 10^{5}-270 \times 10^{5}\right)$ & $760 \times 10^{5}$ \\
K1735 & $700 \times 10^{5}$ & $\left(190 \times 10^{5}-930 \times 10^{5}\right)$ & 0.98 \\
& $\left(73 \times 10^{5}-1500 \times 10^{5}\right)$ & $1.3 \times 10^{5}$ & 0.36 \\
CT26 & $1.4 \times 10^{5}$ & $\left(0.76 \times 10^{4}-2.5 \times 10^{5}\right)$ & \\
& $\left(1.2 \times 10^{5}-1.8 \times 10^{5}\right)$ & & \\
\hline
\end{tabular}

Bioluminescence values are given as median number of photons/s in the region of interest (ROI) with the interquartile range in between brackets as shown in Figs. 3 and 4

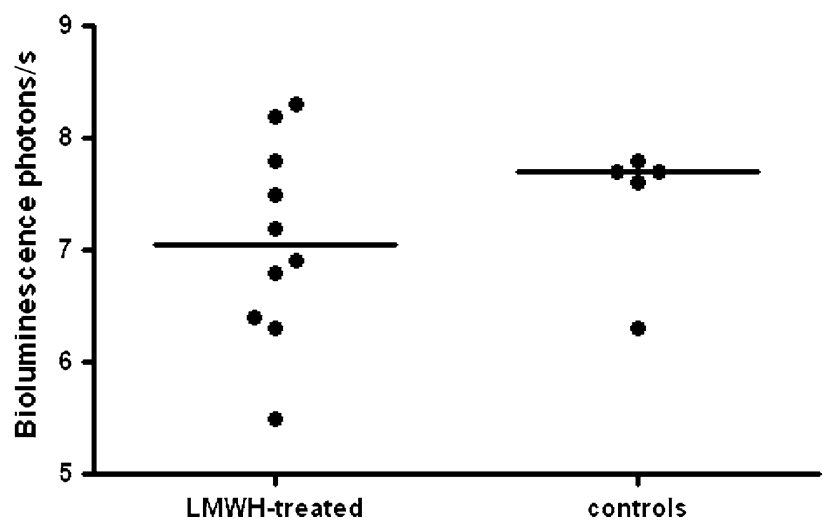

Fig. 5 Bioluminescence in lungs of mice on day 21 after K1735 melanoma cell inoculation in the tail vein. No significant difference is found $(P=0.46)$ between LMWH-treated mice and control mice (bars represent median)

endothelial cells [39], fibronectin and Von Willebrand factor [12, 37]. Inhibition of thrombin by Hirudin may switch off PAR-1 signalling resulting in decreased tumor growth. Indeed, tumor development of B16 melanoma cells was affected by Hirudin and these cells expressed PAR-1 on their surface whereas K1735 melanoma cells did not.
On the other hand, a small fraction of CT26 cells also expressed PAR-1 whereas Hirudin did not have an effect on tumor development of this cell line.

We also investigated the relevance of PAR-4 expression. The role of PAR-4 in cancer is not known, but its expression was upregulated in prostate cancer [40] suggesting that PAR-4 is involved as well. However, none of the three cell lines that we tested expressed PAR-4, indicating that the antitumor effects of Hirudin are not depending on this receptor.

Finally, the difference in the effects of Hirudin on tumor development of the cancer cell lines may be related with adherence to platelets via $\mathrm{P}$ - and $\mathrm{L}$-selectin, to protect the cancer cells against shear stress and the immune system. Importantly, both platelet-cancer cell aggregation and experimental metastasis of human cancer cells were significantly inhibited in P-selectin-deficient mice [41, 42]. Previous reports indicate that $\mathrm{CD} 24$ takes part in metastasis as a ligand of P-selectin. Expression of CD24 as ligand for platelet binding is upregulated by thrombin, indicating that direct inhibition of thrombin may prevent binding of platelets to cancer cells, rendering the cancer cells vulnerable in the circulation [20, 43, 44]. CD24 expression 
was found on B16 cells, in low levels on a small fraction of CT26 cells and it was absent on K1735 melanoma cells. So, the effects of Hirudin on tumor development of B16 melanoma cells in mouse lung can also be explained by inhibition of CD24.

It is likely that all three cell types have been arrested mechanically in the capillaries due to size restriction as was reported by Mook et al. for colon cancer cells in rat liver [45]. Such a process cannot be inhibited by Hirudin. Therefore, it is unlikely that Hirudin has affected interactions between cancer cells and endothelial cells in the lung capillaries.

In summary, the results of our experiments indicate that anticoagulants have their inhibiting effects on tumor development of specific cancer cell types. In our model, anticoagulants affect B16 melanoma but not K1735 melanoma and CT26 colon carcinoma tumor development in lungs. K1735 melanoma and CT26 colon carcinoma cell lines must be independent of thrombin activation, making them insensitive for Hirudin treatment. The B16 melanoma cell line requires a Hirudin target for survival, such as selectin-mediated adhesion and may be the most appropriate murine tumor model for research on the effect of coagulation on cancer.

Acknowledgments We like to thank Mrs. D. Lopes Barreto from the Department of Clinical Chemistry of the Netherlands Cancer Institute and Dr. R.D. Liu from the Center for Experimental and Molecular Medicine of the Academic Medical Center for their excellent technical assistance and Ms. T.M.S. Pierik for the careful preparation of the manuscript.

Open Access This article is distributed under the terms of the Creative Commons Attribution Noncommercial License which permits any noncommercial use, distribution, and reproduction in any medium, provided the original author(s) and source are credited.

\section{References}

1. Büller HR, Van Doornmaal FF, Van Sluis GL et al (2007) Cancer and thrombosis: from molecular mechanisms to clinical presentations. J Thromb Haemost 5(suppl 1):246-254. doi:10.1111/ j.1538-7836.2007.02497.x

2. Blom JW, Doggen CJM, Osanto S et al (2005) Malignancies, prothrombotic mutations, and the risk of venous thrombosis. J Am Med Assoc 293:715-722. doi:10.1001/jama.293.6.715

3. Niers TM, Klerk CP, Dinisio M et al (2007) Mechanisms of heparin induced anti-cancer activity in experimental cancer models. Crit Rev Oncol/Hematol 61:195-207. doi:10.1016/j.critrevonc. 2006.07.007

4. Smorenburg SM, Van Noorden CJ (2001) The complex effects of heparins on cancer progression and metastasis in experimental studies. Pharmacol Rev 53:93-105

5. Altinbas M, Coskun HS, Er O et al (2004) A randomized clinical trial of combination chemotherapy with and without lowmolecular-weight heparin in small cell lung cancer. J Thromb Haemost 2:1266-1271. doi:10.1111/j.1538-7836.2004.00871.x
6. Kakkar AK, Levine MN, Kadziola Z et al (2004) Low molecular weight heparin, therapy with dalteparin, and survival in advanced cancer: the fragmin advanced malignancy outcome study (FAMOUS). J Clin Oncol 22:1944-1948. doi:10.1200/JCO. 2004.10.002

7. Klerk CP, Smorenburg SM, Otten HM et al (2005) The effect of low molecular weight heparin on survival in patients with advanced malignancy. J Clin Oncol 23:2130-2135. doi:10.1200/ JCO.2005.03.134

8. Lebeau B, Chastang C, Brechot JM et al (1994) Subcutaneous heparin treatment increases survival in small cell lung cancer. "Petites Cellules" Group. Cancer 74:38-45. doi:10.1002/10970142(19940701)74:1<38::AID-CNCR2820740108>3.0.CO;2-E

9. Lee AY, Levine MN, Baker RI et al (2003) Low-molecularweight heparin versus a coumarin for the prevention of recurrent venous thromboembolism in patients with cancer. The New Engl J Med 349:146-153. doi:10.1056/NEJMoa025313

10. Hembrough TA, Swartz GM, Papathanassiu A et al (2003) Tissue factor/factor VIIa inhibitors block angiogenesis and tumor growth through a nonhemostatic mechanism. Cancer Res 63:2997-3000

11. Banke IJ, Arlt MJ, Mueller MM et al (2005) Effective inhibition of experimental metastasis and prolongation of survival in mice by a potent factor Xa-specific synthetic serine protease inhibitor with weak anticoagulant activity. Thromb Haemost 94:10841093

12. Hu L, Lee M, Campbell W et al (2004) Role of endogenous thrombin in tumor implantation, seeding, and spontaneous metastasis. Blood 104:2746-2751. doi:10.1182/blood-2004-031047

13. Palumbo JS, Kombrinck KW, Drew AF et al (2000) Fibrinogen is an important determinant of the metastatic potential of circulating tumor cells. Blood 96:3302-3309

14. Broze GJ Jr (1995) Tissue factor pathway inhibitor and the revised theory of coagulation. Ann Rev Med 46:103-112. doi: 10.1146/annurev.med.46.1.103

15. Brüggemann LW, Versteeg HH, Niers TM et al (2008) Experimental melanoma metastasis in lungs of mice with congenital coagulation disorders. J Cell Mol Med (PMID: 18363839)

16. Klerk CP, Smorenburg SM, Spek CA et al (2007) Colon cancer metastasis in mouse liver is not affected by hypercoagulability due to Factor V Leiden mutation. J Cell Mol Med 11:561-568. doi:10.1111/j.1582-4934.2007.00046.x

17. Stevenson JL, Choi SH, Varki A (2005) Differential metastasis inhibition by clinically relevant levels of heparins-correlation with selectin inhibition, not antithrombotic activity. Clin Cancer Res 11:7003-7011. doi:10.1158/1078-0432.CCR-05-1131

18. Ludwig RJ, Alban S, Bistrian R, Boehncke WH, Kaufmann R, Henschler R, Gille J (2006) The ability of different forms of heparins to suppress P-selectin function in vitro correlates to their inhibitory capacity on bloodborne metastasis in vivo. Thromb Haemost 95:535-540

19. Stevenson JL, Varki A, Borsig L (2007) Heparin attenuates metastasis mainly due to inhibition of P- and L-selectin, but nonanticoagulant heparins can have additional effects. Thromb Res 120(suppl 2):S107-S111. doi:10.1016/S0049-3848(07)70138-X

20. Borsig L, Wong R, Feramisco J et al (2001) Heparin and cancer revisited: mechanistic connections involving platelets, P-selectin, carcinoma mucins, and tumor metastasis. Proc Natl Acad Sci USA 98:3352-3357. doi:10.1073/pnas.061615598

21. Chung AW, Jurasz P, Hollenberg MD et al (2002) Mechanisms of action of proteinase-activated receptor agonists on human platelets. Br J Pharmacol 135:1123-1132. doi:10.1038/sj.bjp.0704559

22. Kahn ML, Nakanishi-Matsui M, Shapiro MJ et al (1999) Protease-activated receptors 1 and 4 mediate activation of human platelets by thrombin. J Clin Invest 103:879-887. doi: $10.1172 / \mathrm{JCI} 6042$ 
23. Huo Y, Schober A, Forlow SB et al (2003) Circulating activated platelets exacerbate atherosclerosis in mice deficient in apolipoprotein E. Nat Med 9:61-67. doi:10.1038/nm810

24. Bastida E, Escolar G, Ordinas A et al (1986) Morphometric evaluation of thrombogenesis by microvesicles from human tumor cell lines with thrombin-dependent (U87MG) and adenosine diphosphate-dependent (SKNMC) platelet-activating mechanisms. J Lab Clin Med 108:622-627

25. Esumi N, Todo S, Imashuku S (1987) Platelet aggregating activity mediated by thrombin generation in the NCG human neuroblastoma cell line. Cancer Res 47:2129-2135

26. Heinmoller E, Schropp T, Kisker O et al (1995) Tumor cellinduced platelet aggregation in vitro by human pancreatic cancer cell lines. Scand J Gastroenterol 30:1008-1016. doi:10.3109/ 00365529509096346

27. Collen A, Smorenburg SM, Peters E et al (2000) Unfractionated and low molecular weight heparin affect fibrin structure and angiogenesis in vitro. Cancer Res 60:6196-6200

28. Dvorak HF, Senger DR, Dvorak AM (1983) Fibrin as a component of the tumor stroma: origins and biological significance. Cancer Metastas Rev 2:41-73. doi:10.1007/BF00046905

29. Fidler IJ, Kripke ML (1977) Metastasis results from preexisting variant cells within a malignant tumor. Science 197:893-895. doi:10.1126/science. 887927

30. Klerk CP, Overmeer RM, Niers TM et al (2007) Validity of bioluminescence measurements for noninvasive in vivo imaging of tumor load in small animals. BioTechniques 43(Suppl):7-13. doi:10.2144/000112515

31. Kemper EM, Leenders W, Kusters B et al (2006) Development of luciferase tagged brain tumour models in mice for chemotherapy intervention studies. Eur J Cancer 42:3294-3303. doi:10.1016/ j.ejca.2006.07.013

32. Niemetz J (1972) Coagulant activity of leukocytes. Tissue factor activity. J Clin Invest 51:307-313. doi:10.1172/JCI106815

33. Even-Ram S, Uziely B, Cohen P et al (1998) Thrombin receptor overexpression in malignant and physiological invasion processes. Nat Med 4:909-914. doi:10.1038/nm0898-909

34. Massi D, Naldini A, Ardinghi C et al (2005) Expression of protease-activated receptors 1 and 2 in melanocytic nevi and malignant melanoma. Hum Pathol 36:676-685. doi:10.1016/ j.humpath.2005.04.008
35. Yin YJ, Salah Z, Grisaru-Granovsky S et al (2003) Human protease-activated receptor 1 expression in malignant epithelia: a role in invasiveness. Arterioscler Thromb Vasc Biol 23:940-944. doi:10.1161/01.ATV.0000066878.27340.22

36. Nierodzik ML, Plotkin A, Kajumo F et al (1991) Thrombin stimulates tumor-platelet adhesion in vitro and metastasis in vivo. J Clin Invest 87:229-236. doi:10.1172/JCI114976

37. Nierodzik ML, Kajumo F, Karpatkin S (1992) Effect of thrombin treatment of tumor cells on adhesion of tumor cells to platelets in vitro and tumor metastasis in vivo. Cancer Res 52:3267-3272

38. Wojtukiewicz MZ, Tang DG, Nelson KK et al (1992) Thrombin enhances tumor cell adhesive and metastatic properties via increased alpha IIb beta 3 expression on the cell surface. Thromb Res 68:233-245. doi:10.1016/0049-3848(92)90081-K

39. Klepfish A, Greco MA, Karpatkin S (1993) Thrombin stimulates melanoma tumor-cell binding to endothelial cells and subendothelial matrix. Int J Cancer 53:978-982

40. Black PC, Mize GJ, Karlin P et al (2007) Overexpression of protease-activated receptors-1,-2, and -4 (PAR-1, -2, and -4) in prostate cancer. Prostate 67:743-756. doi:10.1002/pros.20503

41. Kim YJ, Borsig L, Varki NM et al (1998) P-selectin deficiency attenuates tumor growth and metastasis. Proc Natl Acad Sci USA 95:9325-9330. doi:10.1073/pnas.95.16.9325

42. Ludwig RJ, Boehme B, Podda M et al (2004) Endothelial Pselectin as a target of heparin action in experimental melanoma lung metastasis. Cancer Res 64:2743-2750. doi:10.1158/00085472.CAN-03-1054

43. Koenig A, Norgard-Sumnicht K, Linhardt R et al (1998) Differential interactions of heparin and heparan sulfate glycosaminoglycans with the selectins. Implications for the use of unfractionated and low molecular weight heparins as therapeutic agents. J Clin Invest 101:877-889. doi:10.1172/JCI1509

44. Nelson RM, Cecconi O, Roberts WG et al (1993) Heparin oligosaccharides bind $\mathrm{L}-$ and P-selectin and inhibit acute inflammation. Blood 82:3253-3258

45. Mook OR, Van Marle J, Vreeling-Sindelarova H et al (2003) Visualization of early events in tumor formation of eGFP-transfected rat colon cancer cells in liver. Hepatology 38:295-304. doi:10.1053/jhep.2003.50297 